\title{
Pendidikan hukum kepada pengusaha makanan khas/tradisonal dalam melakukan pendaftaran merek di Desa Pangkalan Jambi Kecamatan Bukit Batu Kabupaten Bengkalis
}

\author{
Ulfia Hasanah*, Firdaus, Setia Putra, Nurahim, dan Samariadi \\ Fakultas Hukum, Universitas Riau \\ * ulfia.hasanah@lecturer.unri.ac.id
}

\begin{abstract}
Abstrak. Salah satu kegiatan industri yang semakin berkembang di Bengkalis adalah usaha dibidang produksi Makanan Khas/Tradisional daerah. Saat ini dikenal beberapa makanan Khas/Tradisional yang diminati, antara lain adalah dodol, Bolu, keripik Bawang dan lain sebagainya. Akan tetapi pengusaha dari produk-produk yang dijual tersebut ada yang belum mendaftarkan mereknya. Padahal akibat dari tidak dilakukannya pendaftaran merek ini memungkinkan terrjadinya pemalsuan atau persaingan tidak wajar tersebut juga sangat dirasakan oleh pelaku usaha dan juga sangat diperlukan perlindungan dari segi merek. Tujuan kegiatan pengabdian adalah memberikan sosialisasi dan pemahaman kepada masyarakat tentang penting pendaftaran merek dan tatacara pendaftaran merek. Kegiatan ini juga dapat meningkatkan kompetensi pengetahuan, ketrampilan, motivasi masyarakat, dan berperan dalam pendaftaran merek. Pentingnya melakukan pendampingan kepada masyarakat dalam melindungi produk-produk yang mereka hasilkan. Kegiatan awal dimlai dari pengambilan informasi masyarakat tentang produk-produk makananan yang ada di desa pangakalan jambi . Teknik pengumpulan data dilakukan dengan cara wawancara, observasi dan analisis dokumen. Adanya produk-poduk lokal yang dihasilkan oleh masyarakat di Desa Pangkalan Jmabi menyebabkan desa ini menjadi pilihan dalam kegiatan pengabdian. Kegiatan pengabdian dilakukan melalui pendekatan secara pribadi dan kelompok masyarakat .. Hasil kegiatan pengabdian ini memperlihatkan antusiasme masyarakat menghadiri serangkaian kegiatan, dan peran aktif masyarakat yang cukup baik. Kegiatan yang dilakukan secara berkesinambungan dan terus menerus memberikan dampak positif bagi pertumbuhan dan perkembangan masyarakat.
\end{abstract}

Kata kunci: pengetahuan hukum; merek; makanan tradisional; bengkalis

\begin{abstract}
One of the growing industrial activities in Bengkalis is the business in the field of production of Traditional / Traditional Foods. Currently known for some typical / traditional foods that are in demand, including dodol, Bolu, Onion chips and others. But there are entrepreneurs of the products sold there who have not registered their brands. Whereas the consequences of not registering a trademark enable the occurrence of counterfeiting or unfair competition which is also greatly felt by business actors and protection of the trademark is also very necessary. The purpose of community service activities is to provide socialization and understanding to the public about the importance of trademark registration and trademark registration procedures. This activity can also increase knowledge competence, skills, community motivation, and role in trademark registration. The importance of providing assistance to the community in protecting the products they produce. The initial activity was initiated by taking information from the community about food products in the Pangangalan Jambi village. Data collection techniques carried out by interview, observation and document analysis. The existence of local products produced by the community in Pangkalan Jmabi Village has made this village a choice in community service activities. Community service activities carried out through personal and community approaches. The results of community service activities showed the enthusiasm of the community attending a series of activities, and the active role of the community was quite good. Activities carried out continuously and continuously have a positive impact on community growth and development.
\end{abstract}

Keywords: legal education; traditional food; brands; Bengkalis 
To cite this article: Hasanah, U., Firdaus, S. Putra, Nurahim, \& Samariadi. 2019. Pendidikan hukum kepada pengusaha makanan khas/tradisonal dalam melakukan pendaftaran merek di Desa Pangkalan Jambi Kecamatan Bukit Batu Kabupaten Bengkalis. Unri Conference Series: Community Engagement 1: 126-129. https://doi.org/10.31258/unricsce.1.126-129

(C) 2019 Authors

Peer-review under responsibility of the organizing committee of Seminar Nasional Pemberdayaan Masyarakat 2019

\section{PENDAHULUAN}

Lalu lintas perdagangan barang dan jasa, setiap barang dan jasa yang diperdagangkan selalu menggunakan merek dagang, sebab sebagaimana diketahui bahwa fungsi dasar merek dagang adalah menjadi pembeda antara produk barang atau jasa dari satu produsen dengan produsen lainnya. Merek berfungsi sebagai tanda pengenal yang menunjukkan asal barang dan jasa, sekaligus menghubungkan barang dan jasa yang bersangkutan dengan produsennya (Djumhana dan Djubaedillah, 2003). Walaupun sudah ada peraturan tentang keharusan pendaftaran merek, namun tidak semua produsen atau pedagang yang memiliki merek atas produk dagangannya melakukan pendaftaran, dalam hal ini adalah produksi-produksi makanan khas/tradisional daerah, padahal makanan khas/tradisional tersebut telah banyak diperdagangkan serta menjadi oleh-oleh apabila kita berkunjung kedaerah-daerah khususnya daerah Kabupaten Bengkalis.

Salah satu kegiatan industri yang semakin berkembang di Bengkalis adalah usaha dibidang produksi Makanan Khas/Tradisional daerah. Saat ini dikenal beberapa makanan Khas/Tradisional yang diminati, antara lain adalah dodol, Bolu, Kasida, keripik Bawang dan lain sebagainya. Akan tetapi pengusaha dari produkproduk yang dijual tersebut ada yang belum mendaftarkan mereknya. Padahal akibat dari tidak dilakukannya pendaftaran merek ini memungkinkan terjadinya pemalsuan atau persaingan tidak wajar tersebut juga sangat dirasakan oleh pelaku usaha dan juga sangat diperlukan perlindungan dari segi merek

\section{MASALAH}

Salah satu kegiatan industri yang semakin berkembang di Kabupaten Bengkalis adalah usaha dibidang produksi Makanan Khas/Tradisional daerah. Bila sebelumnya banyak masyarakat memproduksi makanan Khas/Tradisional tersebut hanya untuk konsumsi keluarga, saat ini mulai dikembangkan produksi dalam skala besar yang tujuannya tentu untuk memenuhi permintaan pasar yang terus meningkat yang saat ini sudah menjadi makanan Oleh-oleh yang selalu dicari oleh wisatawan yang bepergian dan singgah di daerah Provinsi Riau Pada umumnya dan kabupaten Bengkalis. Pengusaha Makanan Khas/Tradisional tersebut pun telah memberikan nama tertentu pada produk yang mereka hasilkan sebagai pembeda dengan hasil produksi jenis lainnya. Sama halnya dengan Provinsi Sumatera barat yang memiliki banyak jenis Makanan Khas/Tradisionalnya, dapat dilihat bahwa setiap wilayah memiliki Makanan Khas/Tradisional, haya saja yang menjadi pertanyaan adalah apakah pengusaha makanan Khas/Tradisional tersebut mendaftarkan Merek Dagangnya atau tidak.

Melihat merek-merek yang ditulis dalam produk-produk tersebut yang penulis belum tau apakah Produkproduk dengan merek-merek tersebut telah didaftarkan pada instansi yang berwenang untuk menerima pendaftaran merek. Hal ini tentu saja merugikan bagi pengusaha apabila dikemudian hari ada pihak lain yang beritikad tidak baik yang kemudian melakukan pendaftaran nama yang sama, akibatnya adalah ada produksi barang dan jasa yang sejenis dan menggunakan nama yang sama, maka pengusaha yang tidak pernah mendaftarkan produk barang/jasa nya tidak akan dapat berbuat apa-apa. Hal-hal seperti ini akan merugikan pengusaha yang telah memupuk nama baik produknya yang kemudian dirugikan oleh pihak yang beritikad tidak baik tersebut

Desa Pangkalan Jambi merupakan sebuah wilayah administrasi di Kecamatan Bukit Batu, Kabupaten Bengkalis, dengan seluas sekitar seribu hektar (1000 ha), yang berpenduduk sekitar 1200 jiwa). Desa tersebut berbatasan dengan Kecamatan Siak Kecil di selatan dan Desa Dompas di utara (Oktaviano, 2018). Ekonomi Penunjang ekonomi masyarakat pangkalan Jambi terdapat dari mata pencaharian masyarakatnya, sebagian masyarakat pangkalan Jambi bergerak di bidang pertanian karet dan sawit, beberapa persen lagi merupakan wira usaha, Pns, dan nelayan (Wikipedia, 2019). 
Desa Pangkalan Jambi merupakan wilayah yang dekat dengan laut, yang mana kita ketahui bersama bahwa laut mempunyai kekayaan sumber daya yan luar biasa. Sebagian kekayaan ini dimanfaatkan oleh masyarakat seperti contoh adalah ikan laut. Ikan laut ini selain langsung dikonsumsi dapat diolah menjadi penganan lainnya seperti kerupuk. Tetapi sayangnya peredarannya belum meluas dan mereknya belum mengikuti peraturan yang berlaku.

\section{METODE PENERAPAN}

Kegiatan Penyuluhan ini merupakan salah satu cara untuk meningkatkan pengetahuan dan kesadaran masyarakat tentang pentingnya pendaftaran merek dan akibat dari merek yang tidak didaftarkan. Kepada masyarakat juga diberikan penyuluhan tentang pendaftaran merek, tatacara pendaftaran merek dan akibat hukum dari merek yang tidak didaftarkan, sehingga masyarakat akan menyadari dan memahami pentingnya pendaftaran meek bagi kelangsungan usaha mererka. Kegiatan ini juga dilakukan untuk meningkatkan kesadaran hukum masyarakat tentang akibat dari merek yang tidak didaftarkan. Diharapkan juga permasalahan-permasalahan yang terjadi terkait dengan pelanggaran merek dapat diminimalisir.

Program ini adalah program kemitraan perguruan tinggi dengan masyarakat yang terdiri dari kegiatan tri darma perguruan tinggi berupa implementasi pembelajaran di bidang kesehatan, hukum dan pendidikan, melalui proses identifikasi masalah dan solusinya melalui penelitian dan pengabdian masyarakat. Terbentuknya tim bina hukum berbasis masyarakat merupakan salah satu langkah sumbangsih yang bisa diberikan Universitas Riau sebagai apresiasi kesediaan masyarakat untuk menjalankan program kemitraan ini.

Demikian tujuan pelaksanaan kegiatan pengabdian masyarakat ini secara khusus adalah meliputi: Meningkatkan kompetensi masyarakat (pengetahuan, keterampilan, motivasi dan peran dengan pembentukan tim bina hukum. Dan melakukan pendampingan dan pembinaan kepada masyarakat yang akan melakukan pendafran merek.

\section{PEMBAHASAN}

Sosialisasi dan penyuluhan dilakukan pada beberapa kelompok masyarakat, yaitu k kepada kelompok masyarakat pelaku usaha, perangkat desa dan anggota PKK di desa Pangkalan Jambi, Kecamatatan Bukit Batu. Kegiatan ini mendapatkan respon yang positif. Dari warga masyarakat. Kegiatan dilaksanakan di kantor Kepala Desa di Pangkalan Jambi, Kecamatan Bukit Batu. Kegiatan ini dilaksanakan pada tanggal 10 juli 2019, acara dimulai pada pukul $10.00 \mathrm{Wib}$. Acara ini diikuti oleh 30 (Tiga puluh) orang peserta. Kepala Desa dalam acara ini sekaligus sebagai pembuka acara. Hadir juga Sekretaris Desa, Ketua LKMd, Babinsa serta tokohtokoh masyarakat lainnya. Peserta sosialisasi sangat antusias untuk mengikuti acara ini karena mereka menyadari bahwa bekal pengetahuan yang mereka dapatkan nantinya akan bermanfaat untuk meningkatkan pengetahuan mereka terkait merek. Diharapkan kelompok sasaran ini dapat berkontribusi agar dapat meningkatkan pengetahuan masyarakat tentang merek dan masyarakat sebagai pelaku usaha agar segera melakuakn pendaftaran merek.

Acara penyuluhan dimulai dengan sambutan dari Kepala Desa Pangkalan Jamibi, Kecamatan Bukit Batu, Bengkalis, kemudian sambutan serta perkenalan dari Tim Pengabdian Desa Binaan Fakultas Hukum Universitas Riau, yang diwakili oleh Dekan Fakultas Hukum Universitas Riau. Kegiatan ini juga bersempena dengan penandatanganan MOU antara Fakultas Hukum Universitas Riau dengan Desa Pangkalan Jamb, Kecamatan Bukit Batu, Kabupaten Bengkalis. Acara kemudian dilanjutkan dengan presentasi tentang Urgensi Merek dan Tatacara pendaftaran merek. Dalam penyuluhan ini dijelaskan tentang Peraturan Perundangundangan yang mengatur Tentang Merek, Fungsi Merek, syarat-syarat pendaftaran merek serta Akibat Hukum dari tidak dilakukannya pendaftaran merek. Selanjutnya pada akhir materi, diberikan kesempatan kepada peserta Sosialisasi untuk diskusi dimana para peserta bebas bertanya tentang Syarat-syarat yang harus dipenuhi jika seseorang akan melakukan pendaftaran merek, tatacara pendaftaran merek, biaya pendaftaran merek, jangka waktu perlindungan merek. Kepada peserta juga diberikan brosur tentang merek

Setelah kegiatan sosialisasi ini dilakukan, kegiatan selanjutnya adalah pembentukan tim bina bina hukum. Diharapkan dengan dibentuknya tim bina hukum ini akan memberikan pendampingan kepada masyarakat dan memberikan pengetahuan tentang merek dan urgensi merek bagi pelaku usaha. Kegiatan pengabdian dapat dilihat pada Gambar berikut. 


\section{KESIMPULAN}

Hasil pengabdian ini menunjukkan bahwa masyarakat belum memiliki pemahaman yang memadai dalam memahami pentingnya melakukan pendaftaran merek. Penyuluhan dan pembinaan secara berkesinambungan diharapkan mampu merubah pemahaman masyarakat tentang penting merek.

\section{DAFTAR PUSTAKA}

Djumhana, M., dan R. Djubaedillah. 2003. Hak Milik Intelektual Sejarah Teori dan Prakteknya di Indonesia Edisi Revisi, Cetakan Ketiga. Bandung: PT. Citra Aditya Bakti.

Oktaviano, D. 2018. Profil MPA Desa Pangkalan Jambi: Penjaga Api di Perbatasan Bukit Batu. http://www.riaubiru.com/2018/12/profil-mpa-desa-pangkalan-jambi-penjaga 14.html Diakses pada 14 Februari 2019.

Saidan, H. O. 2004. Aspek Hukum Hak Kekayaan Intelektual (Intellectual Property Right). Jakarta: PT. Raja Garfindo. Wikipedia. 2019. Pangkalan Jambi, Bukit Batu, Bengkalis. https://id.wikipedia.org/wiki/Pangkalan_Jambi,_Bukit_Batu,_Bengkalis Diakses pada 15 April 2019. 